ОРИГИНАЛНИ НАУЧНИ РАДОВИ

ОРИГИНАЛЬНЫЕ НАУЧНЫЕ СТАТЬИ

ORIGINAL SCIENTIFIC PAPERS

\title{
WHAT COULD HAPPEN AFTER THE FIRST WAVE OF COVID-19 DIFFUSION IN ITALY: LEARNING FROM THE 1918 INFLUENZA PANDEMIC
}

\author{
Nicola Fabiano ${ }^{a}$, Stojan N. Radenovićb \\ a Ton Duc Thang University, Faculty of Mathematics and Statistics, \\ Ho Chi Minh City, Vietnam; \\ Ton Duc Thang University, Nonlinear Analysis Research Group, \\ Ho Chi Minh City, Vietnam, \\ e-mail: nicola.fabiano@tdtu.edu.vn, corresponding author, \\ ORCID iD: (1)https://orcid.org/0000-0003-1645-2071 \\ ${ }^{\mathrm{b}}$ University of Belgrade, Faculty of Mechanical Engineering, \\ Belgrade, Republic of Serbia, \\ e-mail: radens@beotel.net, \\ ORCID iD: : $h$ ttps://orcid.org/0000-0001-8254-6688
}

DOI: 10.5937/vojtehg68-26500; https://doi.org/10.5937/vojtehg68-26500

FIELD: Mathematics

ARTICLE TYPE: Original scientific paper

Summary:

Introduction/purpose: A comparison of the 1918 "Spanish" influenza to the 2020 COVID-19 pandemic could shed some light on the evolution of the latter.

Method: A mathematical method previously applied to the description of the behavior of the spread of COVID-19 in time is used this time to the 1918 influenza.

Results: The obtained results were compared and some conclusions made about some possible forecasts for the next waves of COVID-19. Conclusions: Some further waves of the 2020 pandemic should be expected in the future.

Keywords: 1918 Influenza, Coronavirus, COVID-19, differential equation, data fit.

\section{Spanish Influenza and a mathematical model}

In 1918, the influenza pandemic known as "Spanish" caused, according to some estimates, about 50 million deaths worldwide, with about 500 million infected, about one third of world population 
(Taubenberger \& Morens, 2006, pp.15-22). The disease, considered the deadliest pandemic that ever happened, was spread in more waves across the years 1918 and 1919. In Figure 1, we show the death counts per thousands for the population of the United Kingdom in the period 1918-1919.

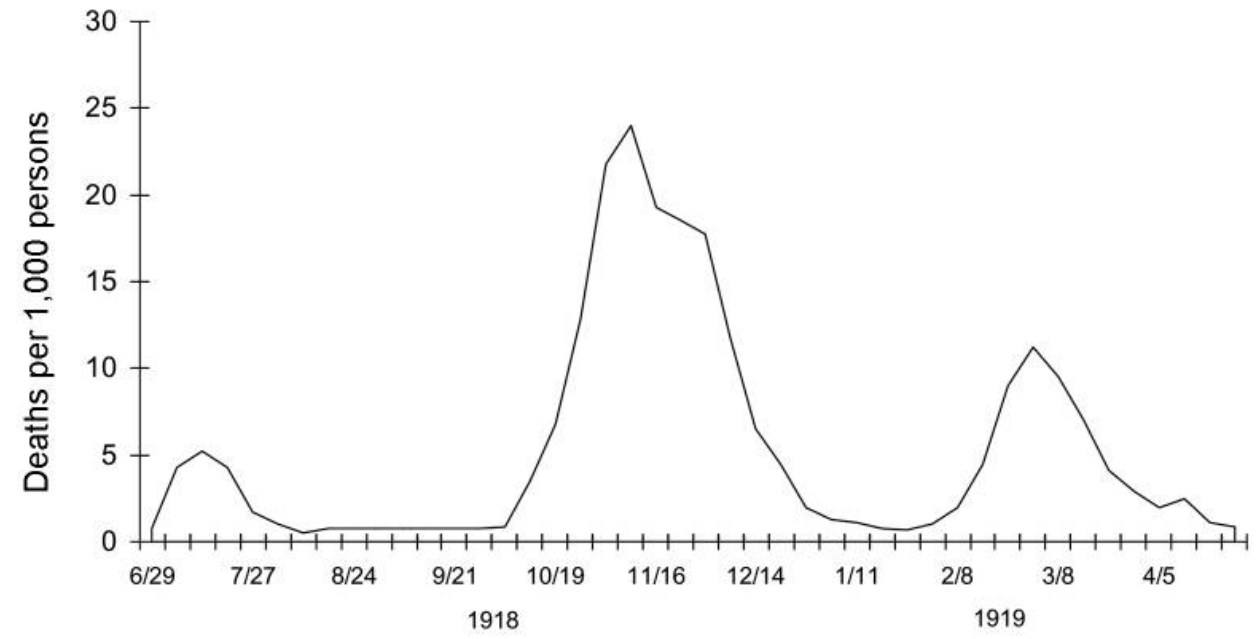

Figure 1 - Keywords: Spanish influenza deaths per thousands in the United Kingdom for the period 1918-1919

Puс. 1 - Ключевые слова: Число смертных случаев (в тысячах) от испанского гриппа в Соединенном Королевстве в период с 1918 по 1919 год

Слика 1 - Кључне речи: број смртних случајева у хиљадама од шпанског грипа у Уједињеном Краљевству у периоду 1918-1919.

In (Fabiano \& Radenović, 2020, pp.216-224) a mathematical model of population growth due to (Verhulst, 1838, pp.113-121) was used to describe the spread in time of COVID-19 for the Italian population. Even though the model used only three parameters, it showed an excellent agreement with the available data.

In summary, the number of cases of COVID-19 in the population as a function of time, $x(t)$, is given by the differential equation

$$
\frac{d x(t)}{d t}=\frac{x(t)}{a}\left(1-\frac{x(t)}{c}\right)
$$

with a solution given by

$$
x(t)=\frac{c}{1+\exp ((b-t) / c)}
$$


where in particular the variation of cases in time is explicitly written as

$$
\frac{d x(t)}{d t}=\frac{c}{a} \frac{\exp [(b-t) / a]}{(1+\exp [(b-t) / a])^{2}} .
$$

The parameters $a, b$, and $c$ are to be determined with a fit to the data, in particular $a$ and $c$ are linked to the height and width of the bellshaped function (3), while $b$ translates in time its maximum value, which is $c /(4 a)$. We will use the same model in order to describe the peaks of the 1918 influenza shown in (1). As there is no numerical data available for this figure, we had to resort to software extraction of the above data from (1). Subsequently, we isolated every visible peak and fitted it with (3), determining for each case the parameters $a, b$, and $c$. The results are shown ordered in time starting from the earliest occurrence of a peak. The abscissa shows the number of days from the start of the peak.

The zeroth peak:

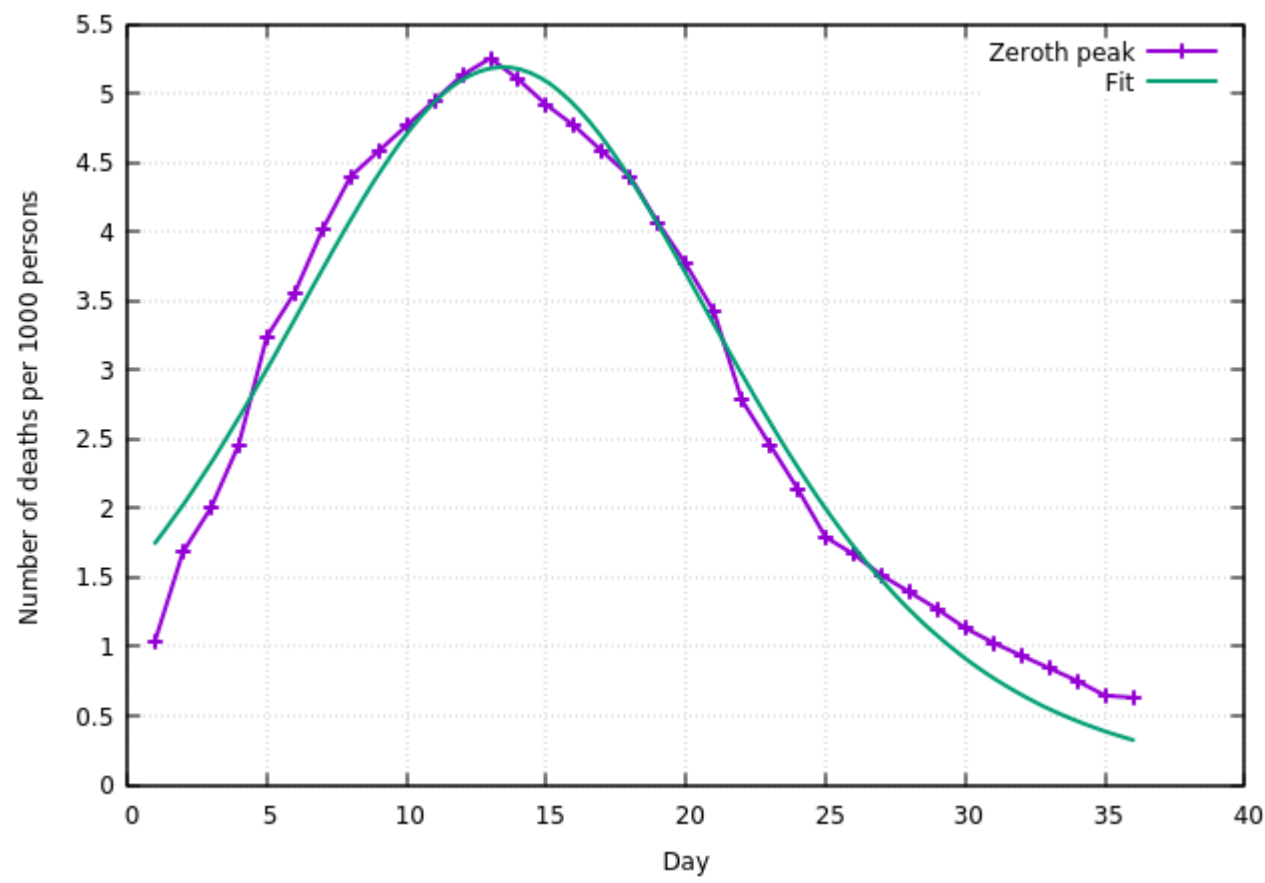

Figure 2 - Zeroth peak

Pис. 2 - Нулевой пик

Слика 2 - Нулти пик 
Table 1 - Fit parameters for the peak in Figure 2

Таблица 1 - Согласованные параметры пика на рис. 2

Табела 1 - Параметри уклапања за пик на слици 2

\begin{tabular}{|l|l|l|l|}
\hline Parameter & Value & Error & Error \% \\
\hline$a$ & 5.46429 & 0.1222 & 2.236 \\
\hline$b$ & 13.452 & 0.1553 & 1.154 \\
\hline$c$ & 113.44 & 1.96 & 1.728 \\
\hline
\end{tabular}

The first peak:

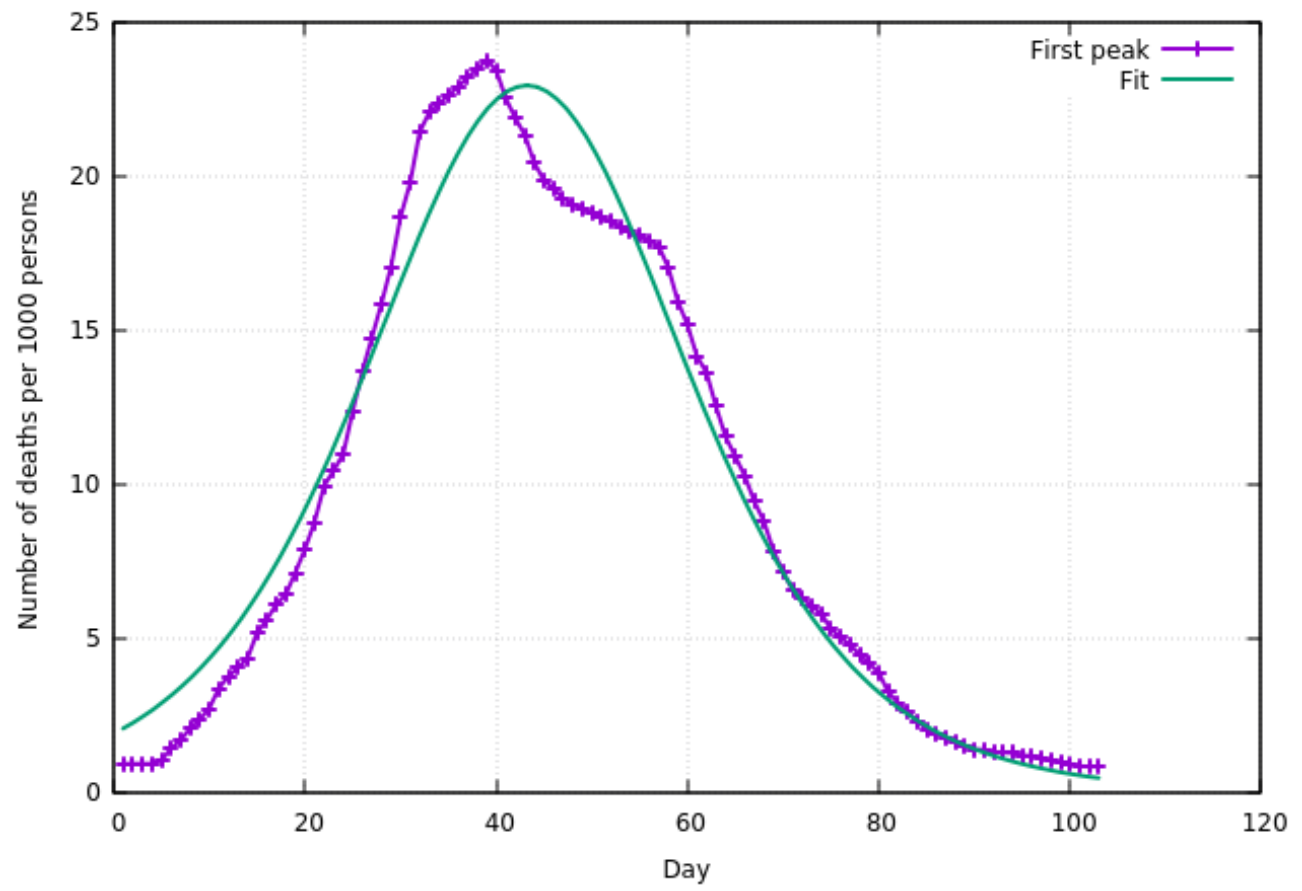

Figure 3 - First peak

Puc. 3 - Первый пик

Слика 3 - Први пик 
Table 2 - Fit parameters for the peak in Figure 3

Таблица 2 - Согласованные параметры пика на рис. 3

Табела 2 - Параметри уклапања за пик на слици 3

\begin{tabular}{|l|l|l|l|}
\hline Parameter & Value & Error & Error \% \\
\hline$a$ & 11.2462 & 0.2014 & 1.791 \\
\hline$b$ & 43.2221 & 0.2806 & 0.6491 \\
\hline$c$ & 1031.4 & 14.79 & 1.434 \\
\hline
\end{tabular}

The second peak:

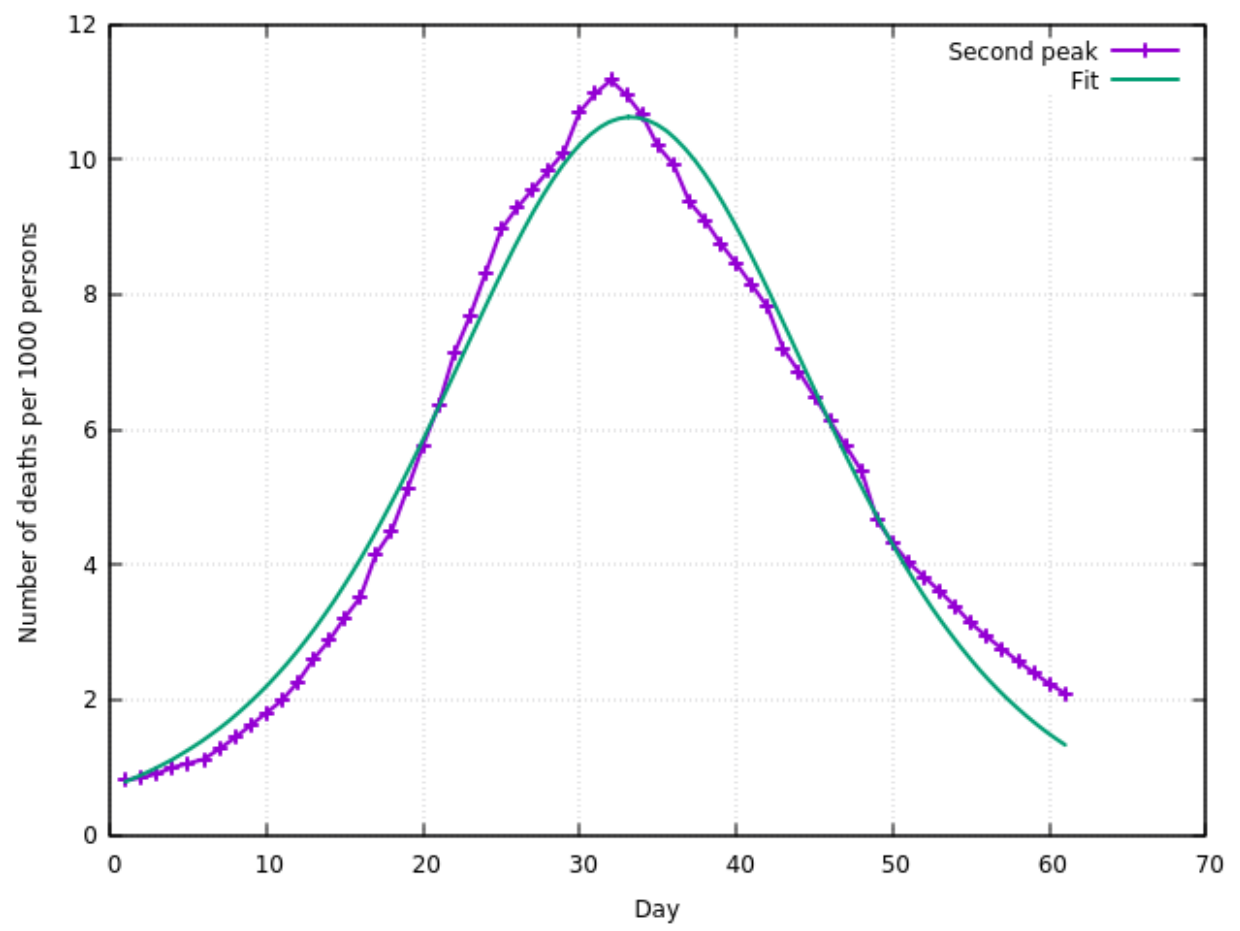

Figure 4 - Second peak

Puc. 4 - Второй пик

Слика 4- Други пик 
Table 3 - Fit parameters for the peak in Figure 4

Таблица 3 - Согласованные параметры пика на рис. 4

Табела 3 - Параметри уклапања за пик на слици 4

\begin{tabular}{|l|l|l|l|}
\hline Parameter & Value & Error & Error \% \\
\hline$a$ & 8.1634 & 0.1196 & 1.465 \\
\hline$b$ & 33.2618 & 0.1621 & 0.4875 \\
\hline$c$ & 347.021 & 4.02 & 1.158 \\
\hline
\end{tabular}

The (possible) third peak:

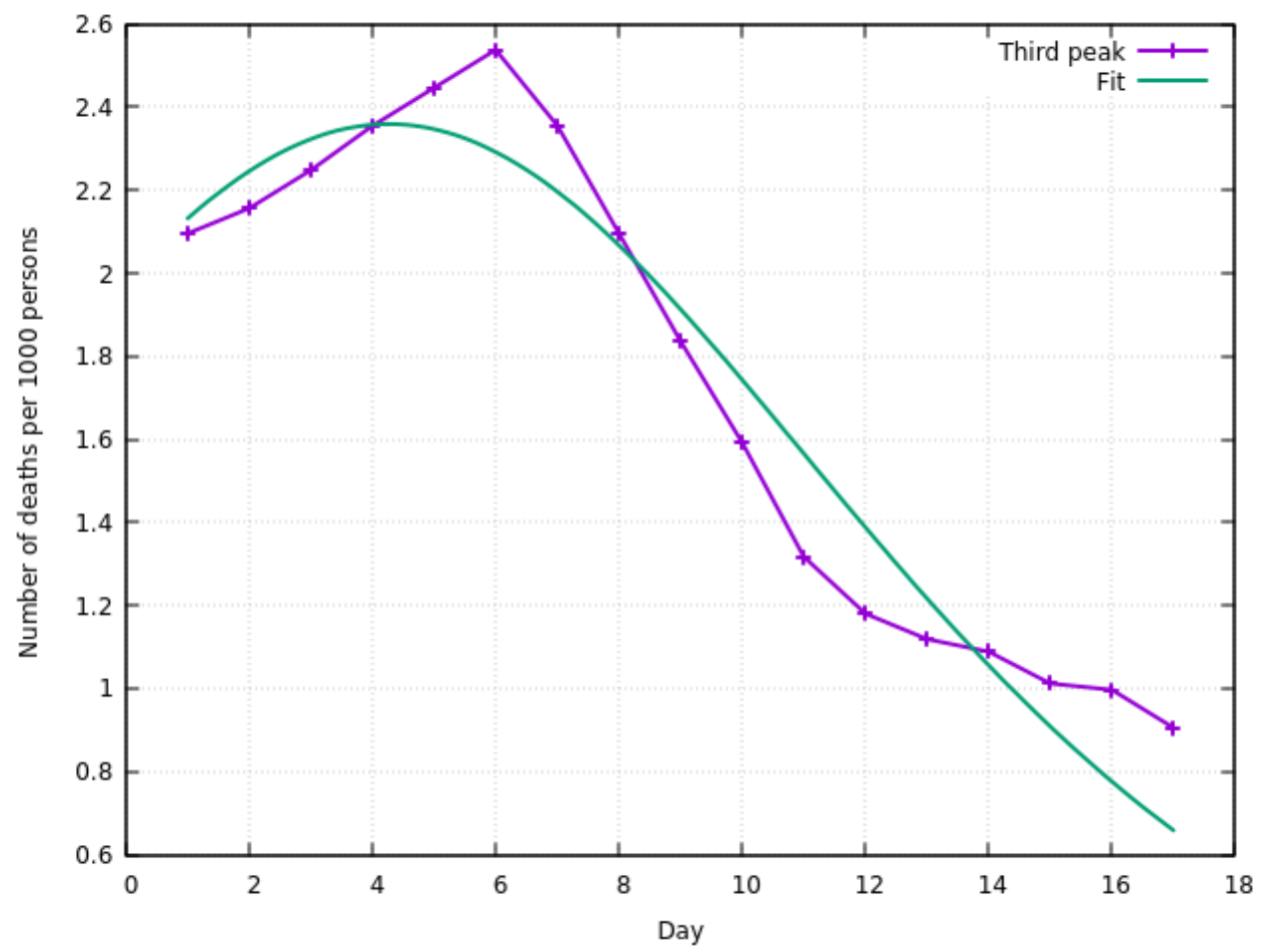

Figure 5 - Third peak

Pис. 5 - Третий пик

Слика 5-Трећи пик 
Table 4 - Fit parameters for the peak in Figure 5

Таблица 4 - Согласованные параметры пика на рис. 5

Табела 4 - Параметри уклапања за пик на слици 5

\begin{tabular}{|l|l|l|l|}
\hline Parameter & Value & Error & Error \% \\
\hline$a$ & 5.08329 & 0.4081 & 8.029 \\
\hline$b$ & 4.26393 & 0.5602 & 13.14 \\
\hline$c$ & 47.9721 & 3.584 & 7.471 \\
\hline
\end{tabular}

As we can see, the agreement of eqs. (1) and (3) with the peaks found in Fig. (1) is excellent. The relative error of the parameters is almost always less than $2 \%$ for the first three peaks, as per Tables (1), (2), and (3). Even with the unclear last peak shown in Fig. (5), the relative error of the parameters is of the order of $10 \%$, in Table (4).

These results show that the mathematical description of a pandemic given by equation (1) is once again very accurate.

\section{Relation to COVID-19}

Our aim now is to apply what we have learned from the 1918 pandemic to the evolution of the 2020 pandemic. The relaxation of quarantine rules could lead to other peaks of cases as seen in the 1918 case, when the second peak was much higher than the first.

In Table 5, we report the height of the four peaks found for the 1918 influenza and their relative heights normalized to the largest one. We also show the $c$ parameter values and again their relative values normalized to the largest one, obtained again the second peak encountered. The $c$ parameter is of particular interest because it is related to the duration of the infection (Fabiano \& Radenović, 2020, pp.216-224): the larger the $c$ value, the longer the length of infection.

We had normalized here the peaks to the largest one, which actually belongs to the second wave of infection and not to the first one. Even in this more favorable case, one could expect that the next infection wave would have an intensity of almost half of the first one (about $46 \%$ ), for a total number of cases of a third (about 33\%). The third and the last wave would have an intensity of about $10 \%$ of the original one, and a relative total number of cases of about $5 \%$. 
Table 5 - Heights and relative heights together with the $c$ parameter and its relative values of peaks in Figure 1

Таблица 5 - Высоты и относительные высоты вместе с параметром с и его относительными значениями пиков на рис. 1

Табела 5 - Висине и релативне висине заједно са параметром с и његовим релативним вредностима пикова на слици 1

\begin{tabular}{|l|l|l|l|l|}
\hline Peak n. & Height & Rel. to max height \% & c & Rel. to max c \% \\
\hline 1 & 22.928 & 100.0 & 1031.4 & 100.0 \\
\hline 2 & 10.627 & 46.352 & 347.021 & 33.646 \\
\hline 0 & 5.190 & 22.637 & 113.44 & 10.999 \\
\hline 3 & 2.359 & 10.290 & 47.9721 & 4.651 \\
\hline
\end{tabular}

All this of course in the case that the first wave was the strongest one. If this is not the case, from Table 5 we see that the relative height of the first two waves is almost 4-fold, while the $c$ value is 9 times larger.

Notice that even in the so-called Hong Kong pandemic flu of 1968 the second wave was much deadlier than the first one (Rogers, 2020).

A few remarks are in order here. First of all, we have compared, because other data were unavailable, the deaths of the United Kingdom for influenza in 1918 to the number of COVID-19 cases in Italy in 2020. This should be acceptable as the population number of the two countries is similar; we assume that the number of deaths in a pandemic is proportional to the number of total cases of the disease, and that the proportionality constant is actually such, i.e. it does not change in time during the pandemic.

It should be also clear that the obtained results will provide the relative intensities and duration of the disease, mainly for the lack of data. In 1918, there were no tests available for the positivity of a virus infection, and a virus image was yet to be seen, as the necessary electron microscope was first built in 1931.

Another question of great interest for the current COVID-19 pandemic is when the subsequent peaks would happen. Actually, the speculations on those timings have been a subject of discussion for decades without a definitive answer. One could infer that due to the shorter persistency of this virus to higher temperatures (Fathizadeh et al, 2020) the next wave could occur in the next autumn, thus overlapping with the flu season. 


\section{Conclusion}

Using a model of population growth with only 3 parameters, we have verified that it is able to describe the 1918 influenza pandemic extremely well. The same model already described the 2020 COVID-19 pandemic in excellent agreement with data. We have used the results obtained for the various waves of the 1918 disease to try to describe the possible waves for the 2020 disease. According to the data, there are serious possibilities to expect subsequent waves of the COVID-19 infection of the same order of magnitude as the present one. The severity of the possible future situation should suggest constant monitoring of the population for a further outbreak of infection and a plan for an immediate lockdown in this case.

\section{References}

Fabiano, N. \& Radenović, S. 2020. On COVID-19 diffusion in Italy: data analysis and possible outcome. Vojnotehnički glasnik/ Military Technical Courier, 68(1), pp.216-224. Available at: https://doi.org/10.5937/vojtehg68-25948.

Fathizadeh, H., Maroufi, P., Momen-Heravi, M., Dao, S., Köse, S., Ganbarov, K., Pagliano, P., Espsoito, S., \& Kafil, H.S. 2020. Protection and disinfection policies against SARS-CoV-2 (COVID-19). Le infezioni in medicina, 2020, 28(2), pp.185-191 [online]. Available at: https://www.infezmed.it/media/journal/Vol_28_2_2020_8.pdf [Accessed: 8 May 2020].

Rogers, K. 2020. 1968 flu pandemic. In: Encyclopædia Britannica. London: Encyclopædia Britannica, Inc. [online]. Available at: https://www.britannica.com/event/Hong-Kong-flu-of-1968 [Accessed: 8 May 2020].

Taubenberger, J.K. \& Morens, D.M. 2006. 1918 Influenza: the Mother of All Pandemics. Emerging Infectious Diseases, 12(1), pp.15-22. Available at: https://doi.org/10.3201/eid1201.050979.

Verhulst, PF. 1838. Notice sur la loi que la population suit dans son accroissement. Correspondance mathématique et physique, 10, pp.113-121 (in French). 


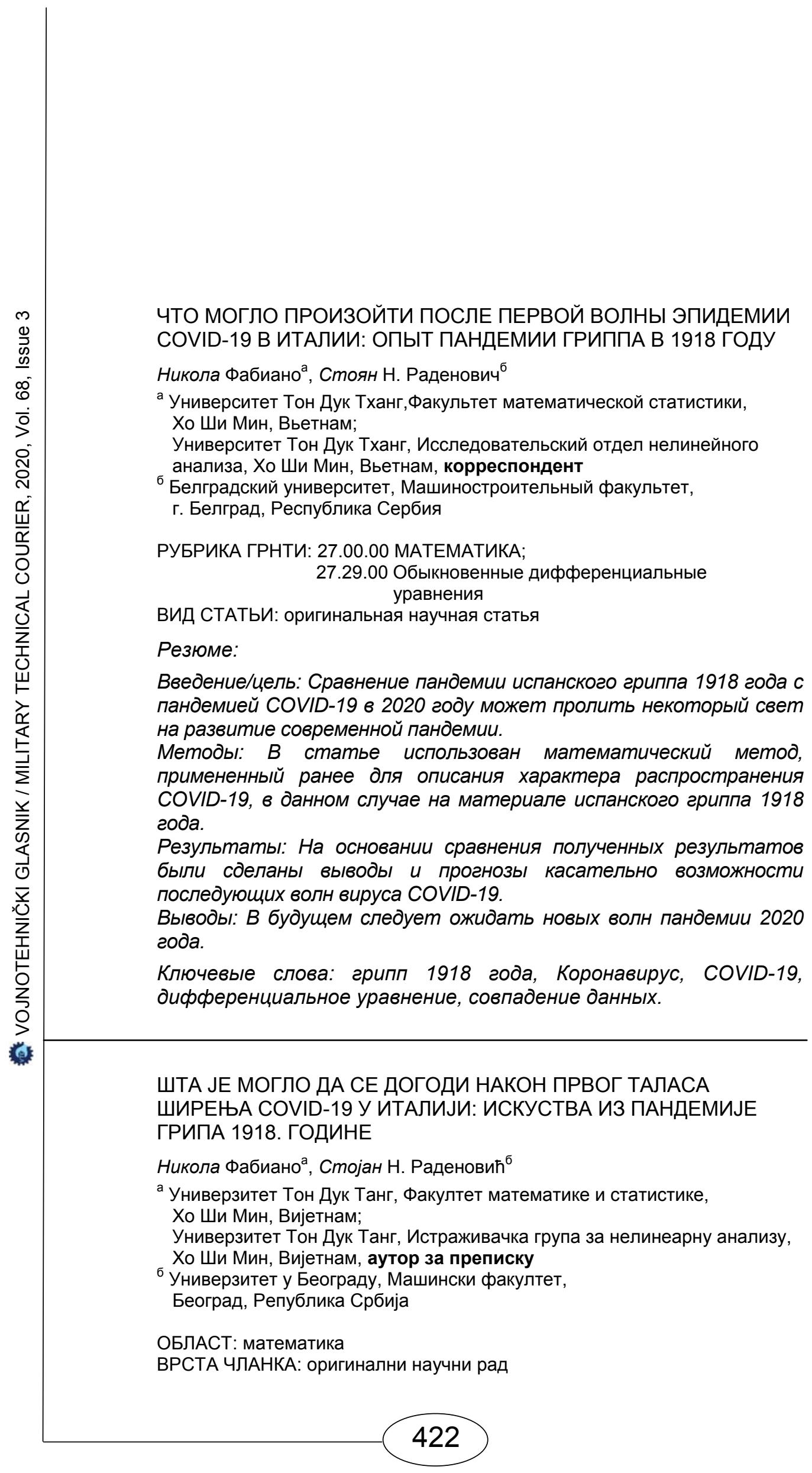




\section{Сажетак:}

Увод/циљ: Поређење шпанског грипа 1918. године са пандемијом COVID-19 могло би донекле разјаснити развој данашње пандемије.

Memode: У раду је коришћена математичка метода која је примењена за опис ширења COVID-19, а овог пута према грипу који је владао 1918. године.

Резултати: Упоређени су добијени резултати на основу којих су изведени закључци о могућим прогнозама за следеће таласе COVID-19.

Закључци: У будућности би требало очекивати нове таласе пандемије COVID-19.

Кључне речи: грип 1918. године, корона вирус, COVID-19, диференцијална једначина, уклапање података.

Paper received on / Дата получения работы / Датум пријема чланка: 08.05.2020. Manuscript corrections submitted on / Дата получения исправленной версии работы / Датум достављања исправки рукописа: 31.05.2020.

Paper accepted for publishing on / Дата окончательного согласования работы / Датум коначног прихватања чланка за објављивање: 01.06.2020.

(C) 2020 The Authors. Published by Vojnotehnički glasnik / Military Technical Courier (www.vtg.mod.gov.rs, втг.мо.упр.срб). This article is an open access article distributed under the terms and conditions of the Creative Commons Attribution license (http://creativecommons.org/licenses/by/3.0/rs/).

() 2020 Авторы. Опубликовано в «Военно-технический вестник / Vojnotehnički glasnik / Military Technical Courier» (www.vtg.mod.gov.rs, втг.мо.упр.срб). Данная статья в открытом доступе и распространяется в соответствии с лицензией «Creative Commons» (http://creativecommons.org/licenses/by/3.0/rs/).

(c) 2020 Аутори. Објавио Војнотехнички гласник / Vojnotehnički glasnik / Military Technical Courier (www.vtg.mod.gov.rs, втг.мо.упр.срб). Ово је чланак отвореног приступа и дистрибуира се у складу са Creative Commons licencom (http://creativecommons.org/licenses/by/3.0/rs/).

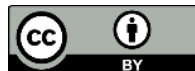

